\begin{tabular}{|l|l|l||}
\hline \multicolumn{2}{|c|}{ PublisherInfo } \\
\hline \hline PublisherName & $:$ & BioMed Central \\
\hline \hline PublisherLocation & $:$ & London \\
\hline \hline PublisherImprintName & $:$ & BioMed Central \\
\hline \hline
\end{tabular}

\title{
Plant sequence completed
}

\begin{tabular}{|l|l|l||}
\hline \multicolumn{2}{|c||}{ ArticleInfo } \\
\hline \hline ArticleID & $:$ & 3863 \\
\hline \hline ArticleDOI & $:$ & $10.1186 /$ gb-spotlight-20001214-02 \\
\hline \hline ArticleCitationID & $:$ & spotlight-20001214-02 \\
\hline \hline ArticleSequenceNumber & $:$ & 300 \\
\hline \hline ArticleCategory & $:$ & Research news \\
\hline ArticleFirstPage & $:$ & 1 \\
\hline \hline ArticleLastPage & $:$ & 3 \\
\hline \hline & $:$ & RegistrationDate : 2000-12-14 \\
ArticleHistory & $:$ & OnlineDate \\
\hline \hline ArticleCopyright & $:$ & BioMed Central Ltd2000-12-14 \\
\hline \hline ArticleGrants & $:$ & \\
\hline \hline ArticleContext & $:$ & 130591111 \\
\hline \hline
\end{tabular}


William Wells

Email:wells@biotext.com

In the 14 December Nature the Arabidopsis Genome Initiative (AGI) announces the completion of the first plant genome sequence. The published sequence covers 115.4 megabases of the estimated 125-megabase genome of the thale cress Arabidopsis thaliana, a model plant. The sequence contains 25,498 genes encoding proteins from 11,000 families. The gene number is high for two reasons: an ancient diploidization, and the presence of 1,528 tandem arrays (containing 4,140 individual genes), which probably arose after unequal crossing-over events during recombination.

After publication of the sequence of Arabidopsis chromosome 2 and chromosome 4 last year, the new reports cover the remaining sequences of chromosomes 1 (Theologis et al., Nature 2000, 408:816-820), 3 (Salanoubat et al., Nature 2000, 408:820-822) and 5 (Tabata et al., Nature 2000, 408:823-826). There is also a lengthy analysis of the whole sequence by the entire AGI team (Nature 2000, 408:796-815).

The analysis includes descriptions of sequence polymorphisms, membrane transport systems, chromatin components, and genes encoded within centromeres. Specific findings include:

- A large number of peptide transporters.- A total number of gene regulators similar to that found in other organisms, but many transcription factors (16 of the 29 classes found in Arabidopsis) appear to be unique to plants.- No genes encoding intermediate filament proteins or structures linking actin to extracellular proteins, but 420 proteins are presumed to function in the synthesis or modification of the cell wall.- An absence of genes for G-proteins of the Ras, Rho, Rac and Cdc42 families, and of genes encoding proteins of several other major signal-transduction pathways (including Wingless/Wnt, Hedgehog, Notch, and JAK/STAT).- Different families of receptor kinases have been expanded to cover developmental processes similar to those seen in other organisms. Receptor tyrosine kinases are lacking in Arabidopsis, although the plant has at least 340 genes for receptor Ser/Thr kinases.- A substantial dose of genes similar to cyanobacterial genes, presumably acquired via the endosymbiont that became the plastid. Many of these genes encode proteins involved in basic metabolic processes.

\section{References}

1. Nature, [http://www.nature.com/nature/]

2. Arabidopsis thaliana: a model plant for genome analysis. 
3. Sequence and analysis of chromosome 2 of the plant Arabidopsis thaliana.

4. Sequence and analysis of chromosome 4 of the plant Arabidopsis thaliana.

5. Cereon Arabidopsis polymorphism collection, [http://www.arabidopsis.org/cereon/]

6. Genomic comparisons of membrane transport systems, [http://www-biology.ucsd.edu/ ipaulsen/ transport/]

7. The plant chromatin database, [http://Ag.Arizona.Edu/chromatin/chromatin.html]

8. Analysis of the genome sequence of the flowering plant Arabidopsis thaliana: rDNA, telomeres and centromeres , [http://preuss.bsd.uchicago.edu/arabidopsis.genome.html]

This PDF file was created after publication. 